\title{
Treatment of non-steroidal anti-inflammatory drug induced enteropathy
}

\author{
I Bjarnason, N Hopkinson, G Zanelli, P Prouse, P Smethurst, J M Gumpel, A J Levi
}

\begin{abstract}
Non-steroidal anti-inflammatory drug induced small intestinal inflammation may have an adverse effect on the joints of patients with rheumatoid arthritis. We therefore assessed small intestinal and joint inflammation in patients with rheumatoid arthritis before and after three to nine months' treatment with sulphasalazine $(n=40)$ and other second line drugs $(n=20)$, while keeping the dosage of nonsteroidal anti-inflammatory drug at the same level. Sulphasalazine significantly decreased the mean (SD) faecal excretion of "'indium labelled leucocytes from $2.39(2.22) \%$ to 1.33 $(1 \cdot 13) \%$ (normal $<1 \%, p<0.01$ ) and improved the joint inflammation as assessed by a variety of parameters. There was no significant correlation between the effects of sulphasalazine treatment on the intestine and the joints. Treatment with other second line drugs had no significant effect on the faecal excretion of 'l'indium (1.58 (1.04)\% and $1.86(1.51) \%$, respectively) but improved joint inflammation significantly. The lack of correlation between the intestinal and joint inflammation and their response to treatment suggests that the two are not causally related.
\end{abstract}

There are numerous observations that suggest an enteric origin for the various arthritides. Both specific and non-specific intestinal infection may cause a non-erosive arthritis ${ }^{1-6}$ and exacerbations of ankylosing spondylitis correlate with serum antibody titres and faecal isolates of klebsiella. ${ }^{7-11}$ Moreover, it is claimed that.inflammation of the ilium correlates with the activity of the joint inflammation in ankylosing spondylitis. ${ }^{12-15}$ Conversely, patients with inflammatory bowel disease may develop a seronegative polyarthritis that is indistinguishable from the peripheral arthritis of Reiter's syndrome and ankylosing spondylitis. ${ }^{16}$ Collectively, this suggests that intestinal infection leads to an interaction between luminal macromolecules and the immune system resulting in disease by the mechanism of simple ${ }^{1718}$ or induced molecular mimicry. ${ }^{11} 1920$

There has recently been renewed interest in the role of the intestine in rheumatoid arthritis since the once fashionable concept of rheumatoid arthritis as a primary autoimmune disease is no longer tenable. Svartz proposed an enteric origin of this disorder in the early 1940s. This has subsequently been supported by findings that fasting or dietary modification and treatment with sulphasalazine, all of which may alter the intestinal flora, may reduce joint inflammation in this disorder. ${ }^{21-28}$ Others have suggested that a proteus infection is important in the patho- genesis. More recent work suggests that the effects of non-steroidal anti-inflammatory drugs (NSAIDs) on intestinal function in rheumatoid patients must be considered. These drugs are claimed to increase intestinal permeability, ${ }^{29-32}$ which may have an adverse effect on the arthritis from leakage of bacterial degradation products and proteases into the circulation ${ }^{19}$ or by the more specific immunological mechanism of molecular mimicry. ${ }^{29}$ Locally, however, increased intestinal permeability caused by NSAIDs subsequently (in more than six months) leads to small intestinal inflammation ${ }^{33}$ with the complications of blood and protein loss, ileal dysfunction, and occasionally strictures. ${ }^{33-36}$ Rooney et $\mathrm{l}^{37}$ seem to have confirmed some of these findings while Segal $e t a l^{38}$ suggest that the intestinal inflammation is a primary abnormality in patients with rheumatoid arthritis. Some deny the presence of inflammation ${ }^{1339}$ and others suggest that NSAIDs have an adverse effect on rheumatoid arthrits. ${ }^{29}$

Because of the conflicting views on the relation between the intestinal inflammation and arthritis, we compared the effects of sulphasalazine and other second line drugs on the intestinal inflammation and joint disease activity in patients with rheumatoid arthritis.

\section{Subjects and methods}

Patients with definite or classic rheumatoid arthritis who fulfilled the criteria of the American Rheumatism Association were recruited for these studies. All had received a variety of NSAIDs but each patient had taken NSAIDs regularly in the preceding nine months and had been taking the same dosage of a single NSAID for at least two months. All patients had active disease that warranted a second line agent for control of symptoms.

The patients were admitted to a metabolic research ward and underwent ${ }^{11}$ indium ("11'Ind) leucocyte studies. Disease activity was independently assessed by a count of the actively affected joints and a global activity index (scale 0-3; no, mild, moderate, or severe limitation of normal activity, respectively) and objectively by measurement of haemoglobin, erythrocyte sedimentation rate, and $\mathrm{C}$ reactive protein.

After assessment a second line drug was given. Twice as many patients were given sulphasalazine as other second line agents (chloroquine, intramuscular gold, and penicillamine). Since the main objective was to relate the possible effect of sulphasalazine on the intestine to that on the joints, the latter group was needed to assess whether disease activity by itself could influence the intestinal inflammation. The second line drug chosen was given independently of the 
"Ind leucocyte values. It was selected at random unless it had been previously used in a particular patient without benefit or it had been withdrawn because of side effects. The treatment period varied from three to nine months, at which time the patients were readmitted to hospital for reassessment. Patients kept to the same dosage of NSAIDs during this time.

Forty patients completed these studies on sulphasalazine (1.5-3.5 g/day) and 20 on other second line agents (six on chloroquine $500 \mathrm{mg}$ / day, decreasing to $250 \mathrm{mg} /$ day; six on intramuscular gold $50 \mathrm{mg} /$ week; and eight on penicillamine $125-500 \mathrm{mg} /$ day). Table I shows their clinical details at the start of the studies.

Ten patients with Crohn's disease of the terminal ileum were studied. These patients were specifically selected because they had not undergone intestinal resection; disease location had been confirmed by barium $x$ ray or endoscopy, or both; they were not on any treatment; and they were asymptomatic (Harvey and Bradshaw Score $<2) .{ }^{40}$ There were six men and four women whose mean age was 28 years (range 19-42 years). These patients underwent "'Ind leucocyte studies before and after six to 12 weeks' treatment with sulphasalazine (2-3 g/ day). Sixteen patients with the irritable bowel syndrome acted as controls for the "Ind leucocyte studies.

These studies were approved by the Harrow Health Authority Ethical Committee, and all subjects gave informed consent to the study.

\section{"IIINDIUM LEUCOCYTE STUDIES}

Sixty millilitres of blood were drawn into a syringe containing $11 \mathrm{ml}$ of acid citrate dextrose (National Institutes of Health formula A) and allowed to sediment at room temperature for two hours in sterile polythene tubes. The supernatant was removed and centrifuged at $100 \mathrm{~g}$ for five minutes. The supernatant was removed and respun at $300 \mathrm{~g}$ for 10 minutes to yield a cell free plasma. The pellet from the $100 \mathrm{~g}$ centrifugation was resuspended and incubated for 10 minutes at room temperature in $0.1 \mathrm{ml}$ HEPES saline buffer (pH 7.4) containing $20 \mathrm{mM}$ HEPES in $0.8 \%$ (v/v) sodium chloride, $4.4 \mathrm{mM}$ tropolone, and 3-400 $\mu \mathrm{Ci}$ (11-15 MBq) "'In $\mathrm{Cl}_{3}$ (Code INSIP, Amersham International, Amersham, Buckinghamshire, UK). Five millilitres of the cell free plasma were then added to the cell suspension and centrifuged at $100 \mathrm{~g}$ for five minutes. The supernatant containing unlabelled Ind was poured off and the labelled cells were resuspended in cell free plasma $(6.0 \mathrm{ml})$. Five millilitres $(7-12 \mathrm{MBq})$ were injected and the rest were used for standards.
TABLE I Clinical details of the patients with rheumatoid arthritis (values, mean (SD))

\begin{tabular}{|c|c|c|c|c|}
\hline Treatment & Male/female & $\begin{array}{l}\text { Age } \\
\text { (range) } \\
\text { (yrs) }\end{array}$ & $\begin{array}{l}\text { Duration of } \\
\text { disease (yrs) }\end{array}$ & $\begin{array}{l}\text { Previous } \\
\text { second line } \\
\text { agents } \\
\text { No }(\%)\end{array}$ \\
\hline Sulphasalazine & $10 / 30$ & $\begin{array}{l}56(11) \\
(31-79)\end{array}$ & $8(9)$ & $22(55)$ \\
\hline $\left.\begin{array}{l}\text { Chloroquine } \\
\text { Gold } \\
\text { Penicillamine }\end{array}\right\}$ & $6 / 14$ & $\begin{array}{l}62(12) \\
(27-82)\end{array}$ & $7(7)$ & $9(45)$ \\
\hline
\end{tabular}

Assuming a $300 \mu \mathrm{Ci}(11 \mathrm{MBq})$ dose of "'Ind is injected, the estimated radiation dose received by the patient during this procedure is 6.5 milliSieverts ( $\mathrm{mSv}$; effective dose equivalent). This is higher than previously published $(4 \cdot 8 \mathrm{mSv}) .^{2831}$

Abdominal scintigrams were obtained one to four hours (early) and 20 hours (late) after injection of the labelled cells using an IGE AT gamma camera with a Star computer at the appropriate channel settings. Individual faecal samples were collected over a four day period after injection of the cells, with particular care taken to avoid contamination with urine. The faecal samples were counted in a bulk sample counter along with a standard $(2 \%$ of the injected dose) which was made up to $200 \mathrm{ml}$ with water and distributed over a fixed amount of filter paper. Each sample was counted for 20 seconds, which enabled the measurement of $0.01 \%$ of the injected dose with a statistical counting accuracy of $\pm 4 \%$.

\section{STATISTICAL ANALYSIS}

Wilcoxon's rank sum test was used for statistical analysis. The differences between sequential values were assessed by the paired Student's $t$ test.

\section{Results}

Patients with the irritable bowel syndrome excreted $0.51(0.23) \%$ (mean (SD)) of the intravenously administered dose of "'Ind leucocytes in the faeces over four days (range $0 \cdot 07-0 \cdot 98 \%$ ). The faecal excretion of "'Ind from the 60 patients with rheumatoid arthritis was $2 \cdot 11$ $(1 \cdot 92) \%$ (range $0.01-11.98 \%$ ) before second line treatment was started. Forty two patients $(70 \%)$ were above the upper limit of normal. There was no significant correlation $(\mathrm{p}>0.5)$ between faecal "'Ind excretion and haemoglobin ( $\mathrm{r}:-0 \cdot 15)$ erythrocyte sedimentation rate $(\mathrm{r}: 0 \cdot 14), \mathrm{C}$ reactive protein $(r: 0 \cdot 08)$, or joint count $(r: 0.01)$.

Table II shows that there was no significant difference in disease activity between patients given sulphasalazine and those given other second line agents. Moreover, values of "'Ind

TABLE II Clinical and laboratory indices of synovial inflammation before and after 2nd line treatment

\begin{tabular}{|c|c|c|c|c|c|c|c|c|}
\hline \multirow[b]{2}{*}{ Treatment group } & \multicolumn{4}{|c|}{ Before treatment (mean $(S D)$ ) } & \multicolumn{4}{|c|}{ After treatment (mean $(S D)$ ) } \\
\hline & $\begin{array}{l}\text { Haemoglobin } \\
(\mathrm{g} / \mathrm{dl})\end{array}$ & $\begin{array}{l}E S R \\
(m m H r)\end{array}$ & $\begin{array}{l}C R P \\
(m g / d l)\end{array}$ & $\mathscr{f C}$ & $\underset{(\mathrm{g} / \mathrm{dl})}{\text { Haemoglobin }}$ & $\begin{array}{l}E S R \\
(m m H r)\end{array}$ & $\begin{array}{l}C R P \\
(m g / d l)\end{array}$ & $\mathcal{F C}$ \\
\hline Sulphasalazine & $11 \cdot 6(1 \cdot 6)$ & $55(29)$ & $7 \cdot 4(7 \cdot 1)$ & $8(4)$ & $12 \cdot 0(1 \cdot 7)$ & $36(29)^{\star}$ & $3 \cdot 4(3 \cdot 2)^{\star}$ & $5(3)^{\star}$ \\
\hline $\left.\begin{array}{l}\text { Gold } \\
\text { Penicillamine }\end{array}\right\}$ & $11 \cdot 2(1 \cdot 8)$ & $64(30)$ & $10 \cdot 6(6 \cdot 4)$ & $8(3)$ & $12 \cdot 1(1 \cdot 8)^{\star}$ & $40(23)^{\star}$ & $6 \cdot 4(4 \cdot 8)^{\star}$ & $5(3)^{\star}$ \\
\hline
\end{tabular}

ESR: Erythrocyte sedimentation rate; CRP: C reactive protein (normal $<0.5 \mathrm{mg} / \mathrm{dl}$ ); JC: Joint count.

$\star$ Significantly different from pretreatment values $(\mathbf{p}<0 \cdot 05)$. 


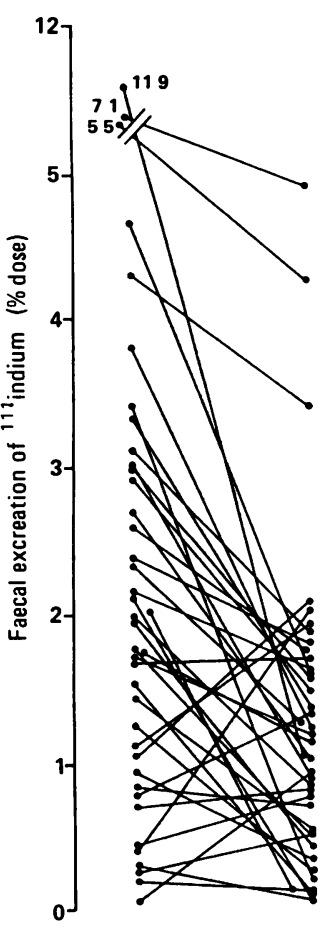

Figure 1: Faecal "'indium excretion in patients with rheumatoid arthritis before and after three to nine months' treatment with sulphasalazine. The upper limit of normal is $1 \%$.

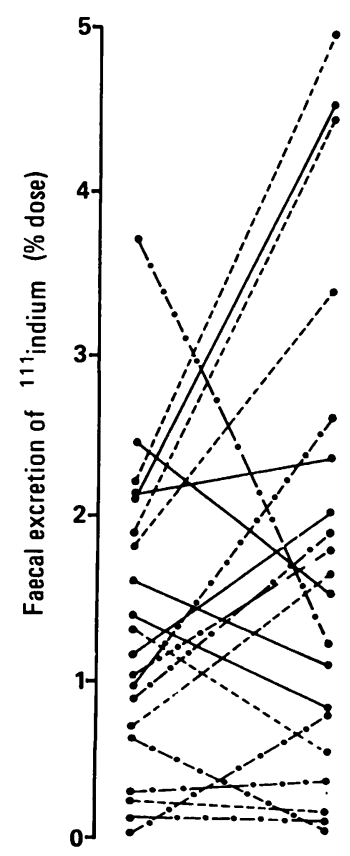

Figure 2: Faecal "'indium excretion in patient with rheumatoid arthritis before and after three to nine months' treatment with penicillamine (uninterrupted line), chloroquine (broken line) and gold (interrupted line with dots). leucocyte faecal excretion before treatment did not differ between the two groups $(2 \cdot 39(2 \cdot 22) \%$ and $1.58(1.04) \%(\mathrm{p}>0.05)$ respectively).

Figure 1 shows the faecal excretion of "'Ind before and after sulphasalazine treatment. The faecal excretion fell significantly from 2.39 $(2 \cdot 22) \%$ to $1.33(1 \cdot 13) \%(\mathrm{p}<0.01)$. Table II shows the values for haemoglobin, erythrocyte sedimentation rate, $C$ reactive protein, and joint count after treatment. There was a significant improvement in all parameters except the haemoglobin concentration. There was no significant correlation between changes in faecal "'Ind excretion and the changes in haemoglobin $(\mathrm{r}:-0 \cdot 15)$, erythrocyte sedimentation rate $(\mathrm{r}$ : 0.01 ), $C$ reactive protein ( $r: 0.09$ ), joint count $(\mathrm{r}:-0 \cdot 19)$, and the global disease activity scale (r: 0.01) during sulphasalazine treatment. When subjects with high rates of excretion ("11Ind $>1 \%$ ) were analysed separately as a subgroup, the correlation coefficients were similar to those reported for the whole group and were not statistically significant.

Figure 2 shows the faecal excretion of "'Ind before and after treatment with chloroquine, gold, and penicillamine. There was no significant change in "'Ind excretion before and after treatment $(1.58(1.04) \%$ and $1.86(1.51) \%$ respectively). Table II shows that haemoglobin, erythrocyte sedimentation rate, $\mathrm{C}$ reactive protein, and joint counts all improved significantly and to a similar extent to results seen with sulphasalazine treatment.

In the patients with Crohn's disease, the "'Ind leucocyte scintigrams confirmed selective localisation of the disease to the terminal ileum in nine of 10 (one being normal). Figure 3 shows the changes in the faecal "Ind excretion during sulphasalazine treatment. There was a significant decrease in the excretion of "'Ind from 7.43 $(4 \cdot 71) \%$ to $4.72(3.61) \%(p<0.05)$. All patients remained asymptomatic and there was no significant change in their haemoglobin concentration or erythrocyte sedimentation rate.

\section{Discussion}

These results show that inflammation of the small intestine in patients with very active rheumatoid arthritis is unrelated to subjective and objective parameters of joint inflammation. Sulphasalazine was the only second line agent that reduced the small intestinal inflammation. Additionally, since the beneficial effect of sulphasalazine on the joints did not correlate significantly with its intestinal action, these results collectively suggest that the small intestine does not play a major role in exacerbations or the continuing disease activity of rheumatoid arthritis.

The role of the intestine in the pathogenesis of rheumatoid arthritis is much less certain than in the reactive arthritides. $1121-23+1+2$ The three groups who have shown small intestinal inflammation in patients with rheumatoid arthritis differ only in their interpretation of the results. ${ }^{29333738}$ As inflammation is evident in patients with osteoarthritis being treated with NSAIDs, and not in newly diagnosed patients with untreated rheumatoid arthritis, ${ }^{33}$ it seems likely that the inflammation is the consequence of NSAID treatment. The normal ileal biopsy specimen findings in patients with rheumatoid arthritis are quite compatible with the "'Ind leucocyte results as the kinetics of "'Ind leucocyte accumulation and faecal excretion suggest that the inflammation is proximal to the terminal ileum; perhaps in the low jejunum and upper ileum as is seen in experimental animals. ${ }^{12-153343}$ As previously suggested, however, ${ }^{1929}$ there remains the possibility that NSAIDs induce increased intestinal permeability, ${ }^{30-32}$ which may by itself have an adverse effect on the arthritis. In this study there was no significant correlation between the intestinal inflammation and indices of synovial inflammation. Furthermore, as reduced intestinal inflammation after sulphasalazine treatment did not correlate with reduced synovial inflammatory activity, this suggests that the two do not have a causal relation. It is clear, however, that this does not preclude an enteric origin of rheumatoid arthritis since macromolecular absorption or antibody cross reactivity does not necessarily depend on structural mucosal damage.

We do not dispute that sulphasalazine has second line activity in patients with aggressive rheumatoid arthritis. ${ }^{446}$ Whether the parent molecule or sulphapyridine is the active agent is difficult to assess. ${ }^{478}$ There is, however, general agreement from the two large multicentre cooperative studies that sulphasalazine is not effective in patients with Crohn's disease affecting the small intestine. ${ }^{4950}$ Both studies, however, included patients with subacute intestinal obstruction who had undergone multiple intestinal resections and relied on subjective symptomatic responses rather than assessing the intestinal inflammation directly. Asymptomatic patients with small intestinal Crohn's disease had significant intestinal inflammation. This differs from colonic inflammatory bowel disease where there is a good correlation between patients' symptoms and the faecal excretion of "'Ind leucocytes ${ }^{51-53}$ and the extent of colonic inflammation. ${ }^{51-53}$ The high values before treatment may, however, explain why patients with small bowel Crohn's disease can develop strictures before their disease is diagnosed clinically. Sulphasalazine reduced the inflammation in these patients showing that it is indeed active in this disorder, but we do not know whether this is a local or systemic action of the drug or its metabolites. In practical terms, however, it is clear that if prevention of small intestinal strictures is to be a realistic goal additional treatment needs to be given since there was significant inflammation after treatment.

In summary, this study suggests that NSAIDinduced small intestinal inflammation does not contribute to the arthritis of patients with rheumatoid arthritis. Both the arthritis and the intestinal inflammation, however, can be treated successfully with sulphasalazine, in contrast with other second line agents which had no significant effect on the intestinal inflammation. The close similarities between NSAID induced small intestinal inflammation and small intestinal Crohn's disease in respect of complications and treatment suggest that further 


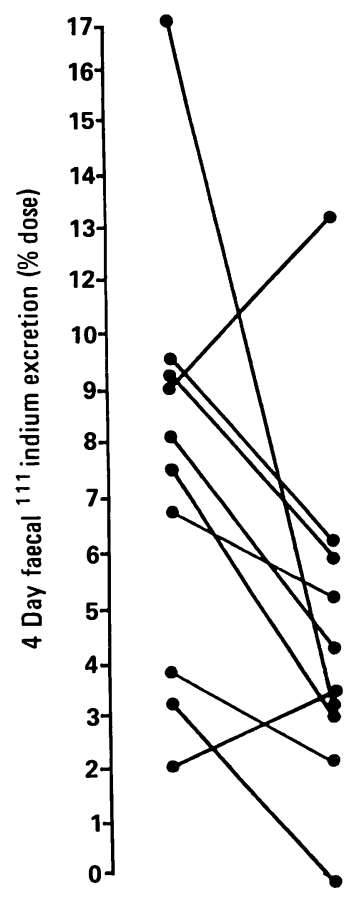

Figure 3: Faecal "'indium excretion in patients with ileal Crohn's disease before and after six to 12 weeks' treatment with sulphasalazine. understanding of the pathogenesis of NSAID enteropathy may have implications for understanding the development of human inflammatory bowel disease.

1 Warren CPM. Arthritis associated with salmonella infections Ann Rheum Dis 1970; 29: 483-7.

2 Noer HR. 'Experimental' epidemic of Reiter's Syndrome. f Am Med Ass 1966; 198: 693-8.

3 Anonymous. Rheumatoid arthritis and the gut [Editorial]. BrMed F 1979; 278: 1104

4 Aho K, Ahvonen P, Lassus A, Sievers K, Tiilikainen A. HL A27 in reactive arthritis. A study of Yersinia arthritis and Reiter's disease. Arthritis Rheum 1974; 17:521-6.

5 Berden JH, Muyntjens HL, Van de Putte LB. Reactive arthritis associated with campylobacter jejuni enteritis. BrMed F 1976; i: 380-1.

6 Wands JR, Lamont JT, Mann E, Isselbacher K. Arthritis associated with intestinal bypass procedure for morbid obesity. Compliment activation and character of circulating cryoprotein. N Engl F Med 1976; 294: 121-4.

7 Ebringer R, Cawdell D, Ebringer A. Association of Klebsiella pneumoniae with acute anterior uveitis. $B r$ Med F 1979; i 383.

8 Ebringer $\mathrm{R}$. Acute anterior uveitis and faecal carriage of gram-

negative bacteria. Br $\mathcal{F}$ Rheumatol 1988; 27 (suppl 2): 42-5.
Ebringer R, Cooke C, Cawdell DR, Cowling P, Ebringer A Ankylosing spondylitis, Klebsiella and HLA-1327. Rheumatol Rehab 1977; 16: 190-6.

10 Ebringer RW, Cadwell DR, Cowling D, Ebringer A. Sequential studies in ankylosing spondylitis: Association of klebsiella pneumoniae with disease. Ann Rheum Dis 1978; 37: 146-51.

11 Ebringer A, Cox NL, Abuljadayel I, et al. Kleibsiella antibodies in ankylosing spondylitis and proteus antibodies in bodies in ankylosing spondylitis and proteus antibodies in
rheumatoid arthritis. Br $\mathcal{F}$ Rheumatol 1988; 27 (suppl II): 72-84.

12 Mielants H, Veys EM, Cuvelier C, De Vos M, Botelberghe L. HLA-B27 related arthritis and bowel inflammation. Part 2. Ileocolonoscopy and bowel histology in patients with HLA B27 related arthritis. $\mathcal{F}$ R heumatol $1985 ; 12: 294-8$

13 Mielants H, Veys EM, De Vos M, Cuvelier C. Gut inflammation in the pathogenesis of idiopathic forms of reactive arthritis and in the peripheral joint involvement of ankylosing spondylitis. In: Mielants H, Veys EM, eds. Spondyloarthropathies. Involvement of the gut.

14 Mielants H, Veys EM, Joos R, Noens L, Clivelier C, De Vos $M$. HLA-antigens in seronegative spondyloarthropathies, $\mathrm{M}$. HLA-antigens in seronegative spondyloarthropathies,
reactive arthritis and arthritis in ankylosing spondylitis: reactive arthritis and arthritis in ankylosing spondylitis:
relation to gut inflammation. $\mathcal{F}$ R heumatol 1987; 14: 466-71.

15 Mielants H, Veys EM, Cuvelier C, De Vos M. Ileocolonoscopic findings in seronegative spondyloarthropathies. $\mathrm{Br} \mathcal{F}$ Rheumatol 1988; 27 (suppl 2): 95-105.

16 Haslock I. Arthritis and Crohn's disease. Ann Rheum Dis 1973 ; 32: 479-86.

17 Weiss EH, Bloemer K, Doerner C, et al. Molecular biology of the HLA-B27 locus. Br $\mathcal{F}$ Rheumatol 1988; 27 (suppl 2): 12-8.

18 Yu BTY. Molecular Mimicry: fact or fiction. $B r \mathcal{F}$ Rheumato: 1988; 27 (suppl 2): 55-7.

19 Walker WA, Iselbacher KJ. Uptake and transport of macromolecules by the intestine. Possible role in clinical disorders. molecules by the intestine. Possible

20 Bjarnason I, Peters TJ. Helping the mucosa make sense of macromolecules. Gut 1987; 28: 1057-61.

21 Svartz N. Salazopyrin A. A new sulfanilamide preparation. Acta Med Scand 1942; 60: 577-98.

22 Svartz N. The treatment for rheumatoid polyarthritis with acid azo compounds. Rheumatism 1948; 4: 56-60.

23 Svartz N. The primary cause of rheumatoid arthritis is an infection. The infectious agent exists in milk. Acta Med Scand 1972; 192: 231-9.

24 Skoldstam L, Larson L, Lindstrom FD. Effects of fasting and lacto-vegetarian diet on rheumatoid arthritis. Scand $\mathcal{f}$ Rheumatol 1976; 8: 249-55.

25 Darlington LG, Ramsey NW, Mansfield JR. Placebocontrolled blind study of dietary manipulation therapy in the management of rheumatoid arthritis. Br $\mathcal{F}$ Rheumatol 1987 ; 25: 115 .

26 Butzler JP. Intestinal microflora in normal individuals and in patients with gut inflammation. In: Mielantis H, Veys EM eds. Spondyloarthropathies. Involvement of the gut. Amsterdam: Excerpta Medica, 1987:281

27 Stephen AM. Effect of food on the intestinal microflora. In:
Hunter JO, Alwin-Jones V, eds. Food and the gut. London: Baillière Tindall, 1985: 57-77.

28 West B, Lendrum R, Hill MJ, Walker G. Effects of sulphasalazine on faecal flora in patients with inflammatory bowel disease. Gut 1974; 15: 960-5.

29 Bjarnason I, Williams P, So A, et al. Intestinal permeability and inflammation in rheumatoid arthritis; effects of nonsteroidal anti-inflammatory drugs. Lancet 1984; ii: $1171-4$.

30 Bjarnason I, Williams P, Smethurst P, Peters TJ, Levi AJ The effect of non-steroidal anti-inflammatory drugs and The effect of non-steroidal anti-inflammatory drugs and
prostaglandin on the permeability of the human small intes tine. Gut 1986; 27: 1292-7.

31 Jenkins RT, Rooney PJ, Jones DB, Bienenstok J, Goodacre $R L$. Increased intestinal permeability in patients with rheumatoid arthritis: a side effect of oral nonsteroida antiinflammatory drug therapy. $B r \mathcal{F}$ Rheumatol $1987 ; 26$ : 103-7.

32 Auer IO, Habscheid W, Hiller S, Gerhards W, Eilles C. Nichtsteroidale antiphlogistika erhohen die darmpermeabilitat. Disch Med Wochenschr 1987; 112: 132-7.

33 Bjarnason I, Zanelli G, Smith $\mathrm{T}$, et al. Nonsteroidal antiinflammatory drug induced intestinal inflammation in man. Gastroenterology 1987; 93: 480-9.

34 Biarnason I, Zanelli, G, Prouse P, et al. Blood and protein loss via small intestinal inflammation induced by nonsteroida via small intestinal inflammation induced by
antiinflammatory drugs. Lancet 1987 ; ii: $711-4$.

35 Bjarnason I, Price AB, Zanelli G, et al. Clinicopathologica features of non-steroidal antiinflammatory drug-induced small intestinal strictures. Gastroenterology 1988;94: 1070- 4 .

36 Lang J, Price AB, Levi AJ, Burke M, Gumpel MJ, Bjarnason I. Diaphragm disease: The pathology of non-steroidal antiinflammatory induced small intestinal stricture. $\mathcal{J}$ Clin Pathol 1988; 41: 516-26.

37 Rooney PJ, Jenkins RT, Smith KM, Coates G. III-Indiumlabelled polymorphonuclear leucocyte scans in rheumatoid arthritis - an important clinical cause of false positive results. Br f Rheumatol 1986; 25: 167-70.

38 Segal AW, Isenberg DA, Hajiprouso V, Tolfree S, Clark J Snaith ML. Preliminary evidence for gut involvement in the pathogenesis of rheumatoid arthritis? Br $\mathcal{F}$ Rheumatol 1986; pathogenesis

39 Meilants H, Vey EM. Nonsteroidal antiinflammatory drugs and the leaky gut. Lancet 1985; i: 218

40 Harvey RJ, Bradshaw JM. A simple index of Crohn's disease activity index. Lancet 1980; i: 514.

41 Bachrach WH. Sulphasalazine: I. An historical perspective. Am F Gastroenterol 1988; 83: 487-96.

42 Svartz N. Sulphasalzine: II. Some notes on the discovery and development of salazopyrin. Am f Gastroenterol 1988; 83 . 497-503.

43 Kent TH, Cardeli RM, Stanler FU. Small intestinal ulcers and intestinal flora in rats given indomethacin. Am $\mathcal{F}$ Pathol intestinal flora in

44 McConkey B, Amos RS, Durham S, Forster PJG, Hubball S Sulphasalazine in rheumatoid arthritis. $B r$ Med $\mathcal{F} 1980$; $\mathrm{i}$ : 442-4.

45 Bax DE, Amos RS. Sulphasalazine, a safe and effective agent for prolonged control of rheumatoid arthritis: A comparison with sodium aurothiomalate. Ann Rheumat Dis 1985; 44: 194-8.

46 Neumann VC, Grindulis KA, Hubball S, McConkey B Wright V. Comparison between penicillamine and sulphasalazine in rheumatoid arthritis. Leeds-Birmingham Trial. BrMed F 1983; 287: 1099-102.

47 Pullar T, Hunter JA, Capell HA. Which component of sulphasalazine is active in rheumatoid arthritis? $\mathrm{Br} \mathrm{Med} \mathcal{F}$ 1985; 290: 1535-8.

48 Taggart AJ, Neuman VC, Hill J, Astbury C, Gallez PL, Dixon JS. 5-aminosalicylic acid or sulphapyridine. Which is the active moiety of sulphasalazine in rheumatoid arthritis? Drugs 1986; 32 (suppl 1): 27-34.

49 Summers RW, Switz DM, Sessions J, et al. National cooperative Crohn's disease study: results of drug treatment. Gastroenterology 1979; 77: 847-69.

50 Malchow H, Ewe K, Brandes JW, et al. European cooperative Crohn's disease study (ECCDS): results of drug treatment. Gastroenterology 1984; 86: 249-66.

51 Saverymuttu SH, Peters AM, Lavender PJ, Hodgson HJ, Chadwick VS. III-Indium autologous leucocytes in inflammatory bowel disease. Gut 1983; 24: 293-9.

52 Saverymuttu SH, Peters AM, Lavender PJ, Pepys MB, Hodgson HJ, Chadwick VS. Quantitative fecal indium-IIIlabelled leucocyte excretion in the assessment of disease in labelled leucocyte excretion in the assessment of
Crohn's disease. Gastroenterology 1983; 85: $1333-9$.

53 Saverymuttu SH, Camillieri M, Rees H, Lavender JP Hodgson HJ. III-indium granulocyte scanning comparison
Horymutu with colonoscopy, histology and fecal III-indium excretion in assessing disease extent and activity in colitis. Gastroenterology 1986; 90: 1121-8. 